\title{
PROPERTY AND PERSONAL SECURITY COMPANIES AS AN IMPORTANT ELEMENT OF THE NATIONAL SECURITY SYSTEM
}

\author{
Andrzej CZOP, PhD \\ Pedagogical University of Cracow \\ kcb.aczop@o2.pl
}

\begin{abstract}
The author presents the results of research carried out in property and personal security companies. The research was carried out both on the basis of a theoretical method based on qualitative analysis of legal acts, critical analysis of scientific literature as well as the empirical method consisting of using research tools such as questionnaires and expert interviews. The research came up with a positive answer to the question: Is it possible to increase the participation of property and personal security companies in ensuring public safety in Poland?

The author believes that it is necessary to create a symbiotic formal and legal system that determines the use of human resources in broadly considered state security and in the process of implementing the objectives of national security policy by all levels of government either, state, local or private.

The author notes that enhancing the efficiency of security entities is possible, inter alia, through continuous technological development and the exchange of knowledge between national security entities and the authorities responsible for managing security through regulation. According to him, the exchange of knowledge, experience and information between the public and private sectors, and the implementation of best practices in the field of security for day-to-day practice, improves the effectiveness of security policy. One such preventive measure is the creation of a formal and legal basis for conducting a security policy based on an integrated system of exploitation of experience, in which all entities responsible for the security of the Republic of Poland participate.
\end{abstract}


This publication indicates the direction of action that the author believes should be taken to make better use of the private security sector in the state security system.

Key words: security system, property and personal Security Companies, specialised armed protection formation, security guard

The modern public safety system consists of government and self-government security institutions, as well as property and personal security Companies. The identified sub-systems have different competences and possibilities of action and contribute to the maintenance of public safety. The system in this meaning is an ordered arrangement of elements whose relations form a certain unity. According to R. Kulczycki, the security system is a comparatively isolated, but in terms of organisation, function, means and normative acts, it is related to a common set of subsystems capable of counteracting threats, guaranteeing constant, sustainable and secure development (Wojnarowski and Babula 2004, p. 14). The organisation of this subsystem is intended to provide conditions for continuous operations during permanent vigilance and emergency response (Kitler and Skrabacz 2003, p. 22). Individual elements of the system carry out routine, ongoing actions to save people's lives, property and the environment, and also neutralising the effects of violent events. It is essential to monitor, prevent and effectively combat these threats (Kitler 2004, p. 110).

L. Korzeniowski includes the following main features of the security system (cf. Korzeniowski 2012, p. 84):

- a common goal and a sense of bond between the structure as a whole and between its individual elements;

- a boundary that defines the range of distinctness from the environment;

- organisational culture considered as values, norms and principles that regulate the actions of individuals and particular cells in the processes occurring in the system;

- the structure of the system, considered as the internal layout and relations between its links;

- interoperability of system components oriented towards fulfilling a goal;

- management governing the activities of the cells forming the structure. 
In order to ensure the effective functioning of the mentioned system, it is essential that all subsystems work together to achieve the basic objective of ensuring public safety. Subsystems operating under different legal regulations and having different institutional subordination are active in the same public space performing public security tasks. The effectiveness and efficiency of the public safety system is the responsibility of the state, as security is one of its principal tasks (cf. Czop 2012, p. 74).

The contemporary conditions of the national security of the Republic of Poland, the intensive development of its economic potential, as well as the increasing involvement in shaping of the national and regional security environment, determine the gradual optimisation of the use of available forces and resources for the construction of an integrated, comprehensive system of defence and national security. This, on the other hand, generates necessity for the creation of a fully symbiotic, both formal and legal, system of defining how to utilise human potential in broadly comprehended state security. In the process of achieving the objectives of national security policy, there are participating entities at the level of: state, self-government and private.

On August 26, 1997, the Parliament of the Republic of Poland adopted the Law on the Protection of Persons and Property (Ustawa z dnia 22 sierpnia $1997 \mathrm{r}$. o ochronie osób i mienia, DzU z 1997 r., nr 114, poz. 740), providing the legal basis for the decentralization of public security. In this way, contractors who carry out commercial business activities have been included in the public safety system, receiving limited powers and responsibility for such an important area that has so far been the state's responsibility. About 5200 security companies employ 114,000 qualified security personnel and 18,000 qualified technical security personnel in Poland. Of this number, 1084 specialised protection formations, of which 265 are internal security services, and 819 are contractors who have obtained the bearer's license for firearms. According to estimates by the Ministry of Internal Affairs, approximately 300,000 people may be employed in the security industry. This is a real force whose effective use in the security system should be of constant concern for the state so it can effectively influence the prevention and combating of threats, both those damaging citizens of the country, as well as its financial and economic interests. (Tomczyk 1999, p. 216) 
It is worth noting that private security companies have taken over security responsibilities in most public places such as banks, airports, ports, offices, drinking water stations and others that were previously protected by state institutions. Hence these objects are often referred to as private police (Gierszewski 2009, p. 171):

The author, acting as the President of the Polish Association of Employers of Protection - Małopolska Branch, who appreciates the importance of personal and property security companies have to fulfill in the security system, decided to carry out research, assuming that real security is only possible in close relation to its evaluation, including the evaluating of Institutions responsible for security (Sułek 2011, p. 39). He acknowledged that research in on the security topic has not only a diagnostic purpose of presenting the state of affairs at a given time, but also, and perhaps above all, a useful objective, so that the results can be used to improve the functioning of the security system. In such a model, the question was of how it expresses the identification and exploration of the subject matter of the research, the question "what is the current state?" relates to the diagnosis of the subject of the research, and the question "how it can be?" is related to the forecasting, that is, the use of research results, to present the best solutions for the future (Wiśniewski 2011, p. 126). The goal of the research carried out by the author was to identify specific solutions aimed at increasing the participation of property and personal security companies in the state security system. The subjects of the research were property and personal security companies protecting as a public safety subsystem.

The research problem was the consequence of the current lack of knowledge about the degree of participation of property and personal security companies in ensuring public safety in Poland. Its formulation has become the starting point for real research. A research problem defined as a research project that should provide a well-defined knowledge, which was incomplete (Kolman 2004, p. 146) at the time the study began, was formulated as a question: "Is it possible to intensify the participation of property and personal security companies in providing public safety?"

In the field of safety studies, mixed methods, both theoretical and empirical, are used. The author took into account criteria such as:

- research subject,

- purpose of research,

- type of research problem (Wiśniewski 2011, p. 137). 
Based on these criteria, the researcher used two basic methods:

- analysis of documents,

- a diagnostic survey.

Heuristic tools are used with these methods (expert and morphological).

The first of them, the analysis of documents, is a qualitative method spreading over the entire study while studying literature, normative acts and source acts (Podgórski 2007, p. 55). A serious limitation was the absence of a broad spectrum of scientific monographs on the functioning of property and personal security companies in the public security system. There have been very few entries on this subject on the market. It was rarely the subject of scientific investigations or explorations.

Another theoretical method used during the research was the quantitative analysis of the results of the statistical studies and then the generalisation of the presented results and the sketching of the conclusions. (cf. George and Bennett 2005, p. 211).

In the selection of the research tools, the author has adopted the principle that they should correspond in the best way to the properties of the subject ${ }^{1}$. Hence, he used a survey method based on surveys and questionnaires. He also used an expert interview as a method that is considered as highly effective and makes it possible to gather the opinion of the authorities in the field of knowledge.

In the survey, the research group, represented by the employees of property and personal security companies numbered 503 people who worked in six companies, of varying capital and employment size. Three of the companies surveyed operate nationwide and have a corporate profile, two operate in a voivodship and one in a local area - a poviat. Anonymous heuristic surveys were conducted in the period from March to August 2013 in Kraków, Warsaw, Katowice, Nowy Sącz and Niepołomice. The aim was to identify the factors limiting the optimum

1 Because of the equivocal way of explaining concepts: tools, techniques and research methods in the literature of the subject, the author accepted in his research literature the interpretations of Ackoff (Ackoff 1969), that: research tools - are physical or conceptual apparatus (instrument) used in scientific research; Research Techniques - is the way of using these tools, research methods - the rules according to which the choice of appropriate techniques is made in science. 
participation of property and personal security companies in providing public safety.

Expert interviews were conducted from June to July 2013 and covered seven people related to the subject of the operation of property and personal security companies. The three interviewees were people holding managerial positions in these economic entities. The next two were policemen occupying: the position of commander of the district police and an expert of the Department of Administrative Procedure of the Provincial Police Headquarters. There were also another two interviews - with the security auditor and the honorary member of the Polish Association of Employers "Protection", former President of the Małopolska Branch of this association. Due to the fact that the interlocutors performed different functions and represented different entities, some questions differed in their form. Also, the number of questions for a particular expert, although they were related to the same issue, was not the same. In each case, however, the answers covered the same issues that were important to the subject of the research.

Heuristic studies using both the Delphi-survey and the morphological methods of expert interviews have yielded consistent results, and with the results of theoretical studies, that is a critical analysis of literature and legislation, have confirmed the complex hypothesis that exploiting the potential of property and personal security companies in public is not enough. Apart from this diagnosis, they also provided the basis for defining actions aimed at increasing the level of participation of the private security sector in the security system. The proposed changes presented by the author of the research refer to the legal, economic and organisational aspects of the private security sector. The main assumption by the author was to improve the quality of the subsystem's cooperation with other subsystems responsible for state security.

Here are the most important findings of the research that have not lost their relevance and should be used to increase the level of participation of property and personal security companies in ensuring safety (cf.: Czop 2014):

Currently, the cooperation of security companies with state institutions responsible for security is based solely on the Regulation of the Ministry of Internal Affairs and Administration dated December 18, 1998 on the detailed 
rules of cooperation between SUFO and the Police, fire protection unit, civil defense and municipal guards (Rozporzadzenie Ministra Spraw Wewnętrznych i Administracji z dnia 18 grudnia 1998 r. w sprawie określenia szczegółowych zasad współpracy specjalistycznych uzbrojonych formacji ochronnych z Policją, jednostkami ochrony przeciwpożarowej, obrony cywilnej i strażami gminnymi (miejskimi),DzU z 1998 r., nr 161, poz. 1108). It indicates that this cooperation is to be conducted with the head of the subject facility for compulsory protection. It should be noted, however, that such a person generally does not have adequate specialist safety training, so in fact he or she cannot be a professional partner to work with the Police (Rozwadowski 2014, pp. 39 - 42). The author believes that working with the Police in the area of defining the terms and conditions of the protection plan (Ustawa z dnia 6 kwietnia 1990 r. o Policji, DzU z 2011 r., nr 287, poz. 1687, z późn. zm., art. 7 , ust. 1) should be conducted by a representative of the company protecting the facility. This person has the adequate knowledge and experience in security and knows what standards should be met by physical protection, technical security and service tactics at security posts or in intervention groups. This person can also make the necessary calculations of the forces and means necessary to ensure the security of his company's facilities ${ }^{2}$.

Taking into consideration the scope of the matter defining the cooperation of SUFO with the Police, it is difficult to imagine that it is, according to the regulations of the Regulation of the Ministry of Internal Affairs and Administration, to be held by the sole person of the manager of the protected unit. Here also, the current interaction, in order to be real and effective, must take place systematically, with the participation of the person managing the object (Bejgier and Stanejko, pp. 168-169).

Studies have revealed an alarming tendency - the total lack of any information held by the Police. This information does not reach either the manager of the facility that is subject to the compulsory protection or the company that protects the facility. It has been shown that commonly, in most cases, arrangement of the protection plan is the last moment of real contact with the Police, which itself

2 Facility - building (building complex) permanent or temporary, occupying a defined area (Bejgier and Stanejko 2010, p. 167). 
does not show any interest in the implementation of the assumptions made in this document.

It was found that there was no provision of basic information needed for the organisation of the protection, which is exclusively possessed by the Police. It includes the following data that determines the manner and tactics of protection duties:

- the degree of a crime threat to a given area,

- the type of events that have occurred recently, the nature of which may be related to the security of the protected area,

- the methods and means of action of persons or groups likely to jeopardise the security of the protected area,

- the place, time and circumstances of the gathering of these people,

- emerging sources of disturbance of peace and order,

- planned events, high-risk events that may affect the security of the protected area,

- preventive and intervention activities undertaken in the immediate vicinity by the Police.

The police also do not report specific proposals in the area of preventive measures that should be carried out by the security firm alone or together with police officers. Such information would enable the security manager to adapt service tactics to current identified threats and make it possible to dislocate forces and resources in a flexible way, taking into account a changing situation, which is not static, but is a process with its own dynamics.

In the course of the study, it was stated that the managers of the security companies often need to acquire the information mentioned above themselves. However, this is exclusively based on private and informal contacts, which are referred to in the literature of the subject as "bluedrain" or "oldboy`s network" (Boon 1999, p. 196). This is not, however, a systemic activity. This communication channel between security companies and police units is not official and transparent; therefore, it does not guarantee good information flow and proper information quality.

There is a lack of clear legal regulations that precisely define areas for possible cooperation between security companies and other formations, while securing mandatory protection facilities is an important public security vulnerability. 
According to the author, this requires amendments to the current Regulation of the Ministry of Internal Affairs and Administration from December 18, 1998, on the detailed rules of cooperation between SUFO and police, fire protection units, civil protection and communal guards (Rozporzadzenie..., op. cit.).

The author notes that the above mentioned normative act only defined cooperation with part of the private security sector, which is a specialised armed protection formation. There are only 1084 such entities in Poland at present. There are currently 5200 licensed property and personal security companies in Poland. Thus, legal regulations defining the cooperation with the government and self-government subsystems do not cover up to 4/5 entities operating in the security industry. These companies perform tasks in areas that are not subject to the mandatory protection. What needs to be considered is the fact that the state does not assume any cooperation with these companies, despite the fact that they perform tasks that were previously covered by the state monopoly.

Another disturbing regularity concluded from the research is that the police do not exploit the potential of security workers. Commanders of Police units do not have clear legal grounds, so they treat security companies like any other entity conducting business activity. Thus, they do not perceive the specific nature of their activities, which consists in providing security. As already indicated, information on potential hazards in areas protected by the private sector is important in the process of setting up security activities. Police have an identification, personal identity and have a knowledge of the geography and dynamics of threats (cf. Szopa 2009). But this information is not provided to private security companies. The cause declared by the Police is the lack of legal definition of the forms and possibilities of cooperation with these entities in the public space, which was not entrusted to them by the client.

Based on the research, it can be stated that security guards, even if they do not have such a legal obligation, often decide to intervene to protect life, health and property outside the area that they protect under the contract. They do it selflessly, in the sense of a social obligation, believing that if they have specific skills, they should be able to effectively help those who need it, even if they are not in their protected area. The security personnel also report to the Police about known irregularities and threats. However, this is the only one-way activity because the Police do not provide information to security staff which they could use to 
give effective support for law enforcement forces. Police do not inform security companies about:

- missing persons,

- wanted dangerous criminals,

- stolen vehicles,

- persons in pursuit.

It is worth noting that this information is not covered by the privacy clause (cf. Ustawa z dnia 5 sierpnia 2010 r. o ochronie informacji niejawnych, DzU z 2010 r., nr 182, poz. 122). In the author's opinion, it is highly probable that, considering the number of sites serviced by private security companies, effectiveness of Police operations would be greater if security guards were involved (cf. Pajorski 2008). Research also shows that security guards are not informed about crime-prone areas that they might be aware of when performing their own tasks. Managers of security companies are ready to take into account the Police's remarks and requirements for these places, when the emergency teams are dispatched (Palczewski and Stach 1999, p. 158). On the one hand, this would provide a preventive effect and, on the other, it would be possible to quickly transmit the information of the observed threat to the police station on duty. Crews of security companies are mobile (Piwowarski and Pajorski 2015, p. 143) and, therefore, can observe a number of security-critical situations or ones that require immediate response from the police. Currently, it is a rare situation that the police inspire security companies to do so, although they could add additional "eyes and ears" operating as threat signal posts. According to the author, this situation could be altered, but it is imperative to create a legal act that would regulate relations between non-SUFO security companies and state security organisations.

A review of the regulatory acts regulating safety issues indicates that there are currently no legal regulations regarding the possibility of establishing and conducting cooperation with private sector security companies by forces responsible for public security other than the Police, Municipal Guard, Civil Defence or Fire Brigades (Rozporzadzenie..., op. cit.). The author believes that cooperation with such entities of the government security sector as the Military Police, Border Guard (Ustawa z dnia 12 października 1990 r. o Straży Granicznej, DzU z 2011 r., nr 116, poz. 6751). Prison Guard, Road Transport Inspection 
(Ustawa z dnia 6 września 2001 r. o transporcie drogowym, DzU z 2012 r., poz. 1265 oraz z 2013 r., poz. 21 i 567), Forest Guard and Railroad Guard, is not only possible but also desirable. The research shows that the tasks and scope of operation of these uniformed formations allow for the use of support from the private security sector. In the case of the Border Guard, Prison Guard, Road Transport Inspection, Forest Guard (Ustawa z dnia 28 września 1991 o lasach, DzU z 2011 r., nr 12, poz. 59 [tekst ujednolicony]) and Railway Guard (Ustawa z dnia 28 marca 2003 r. o transporcie kolejowym, DzU z 2007 r., nr 16, poz. 94, z późn. zm.) the cooperation could take place on similar terms as with the Police. On the other hand, in the case of the Prison Guard (Ustawa z dnia 9 kwietnia 2010 r. o Służbie Więziennej, DzU z 2010 r., nr 79, poz. 523 z późn. zm.) and the Military Police (Ustawa z dnia 24 sierpnia 2001 r. o Żandarmerii Wojskowej i wojskowych organach porządkowych, DzU z 2013 r., poz. 568), it could rely on the rapid transfer of all information regarding threats observed by those companies, within their area of operation, and which are the concern of those public security services. The obligation to make such a signal could be specified in the legal act in the rank of the regulation. This would increase the sense of security structure as a coherent whole.

Research has determined that security guards were not provided with the opportunity to use many of the direct coercion measures that were reserved under the Direct Coercion and Firearms Act for other formations. (Art. 2 ust. 1 pkt 20, Art. 65 pkt 1 Dz. U. z 2013 r. poz. 628) They cannot use handcuffs on the legs or the so-called "complex". (security companies are not equipped with these types of handcuffs as of now). Other formations can use those measures against aggressive detainees in the context of a crime involving the use of firearms, explosives or other dangerous tools. According to the author, in the facility that is liable for mandatory protection by the law, when a security guard takes such a person into custody, they should also be able to use a means that would effectively guarantee elimination of the threat. The legislator also ruled out the use of straitjackets, waist bands and incapacitating grips, as well as safety helmets. It is especially astonishing that a straitjacket or a waist band is used if the use of other means of direct coercion is not possible or may be ineffective, and it is necessary to capture the person, to thwart their escape or to pursue that person. Both these measures are not offensive, and their use does not pose a threat to the life or health of the person to whom they are applied. In the author's opinion, there is no reason 
to deprive security guards of the protection of tools without which, in some situations, their intervention may not be possible. This also applies to the use of incapacitating grips, the use of which is also subsidiary. So in situations like:

- danger to life, health or freedom threatening attack,

- counteracting against attack on protected facilities (Nowicki 1995, p. 135),

- the need to detain a person,

- thwarting the person's escape,

- chasing after a person

when no other means can be used effectively, incapacitating grips are used. They are released from a firearm, but can also be thrown by hand to immobilise a person or animal. Deprivation of the ability to use this measure makes it difficult and sometimes impossible for the security guards to function effectively in the situations described above.

In the research process, it was found that the legislator also significantly reduced the scope of cases in which security guards can use direct coercive measures. These cannot be used for enforcement of the law according to commands given by the security guard, as well as the purpose of counteracting activities directly aimed at threatening the life of a security guard or another person.

The security officer may not use direct coercive measures to counter breaches of public order or security, even for the protection of public order or security in the areas or facilities that it protects. This greatly limits security guard's ability to work effectively.

When a security guard performs a convoy or escort in a protected area, it is not possible to use direct coercive measures to ensure safety. The law also ruled out the use of direct coercion in a situation where a guard defends passive resistance, i.e. when a person refuses to execute a lawful order issued by him, but does not use violence or threats. A security guard cannot apply direct coercive measures to prevent auto aggression activities ${ }^{3}$.

3 Self-aggression is an action or series of actions aimed at causing mental or physical harm, it is an aggression directed "inward". This is a disorder of self-preservation instinct, which tends to self-harm, self-harming health injuries and even self-imposed life threathening. (Sawaściuk, 2003). 
A separate part of the research was devoted to the use of weapons by security personnel. Research has determined that a security guard cannot use a firearm ${ }^{4}$ if he or she pursues a direct attack on a person who has committed an unlawful attempt on life, health, freedom of his or other person, affecting important facilities, equipment or areas, property, in a situation when such offender also posed a threat to life health and freedom. This also applies to the situation of the chase for the most serious crimes, such as terrorist attacks, murder, robbery, serious injury, the risk to life and health on large scale, rape, and taking hostages. A security guard cannot use a weapon when the perpetrators of such offences need to be detained. The author expresses the opinion that in these situations, a security guard should have the legal ability to use a weapon

Another thing to consider is the use of firearms (Ustawa o środkach przymusu bezpośredniego i broni palnej, DzU z 2013 r., poz. 628, art. 4 ust. 9), which means that the shot should be fired with the use of penetrating ammunition in the direction of the animal, object or other direction that does not pose a threat to man. In the current legal status, a firearm can only be used by a security guard if he or she needs to be alerted to a threat or to call for help, and to give a warning shot that is not considered as use of a firearm. A security guard does not, however, have the right to use the weapon to stop a vehicle, even if the vehicle is life-threatening or health-threatening, or threatens important facilities, equipment or areas. A security guard also cannot use a weapon to remove an obstacle preventing or hindering a person's capture or saving values such as property, life or health. One must not use your firearm to neutralise objects or devices that may pose a danger of explosion, causing an immediate threat to health or life. This entitlement does not apply to disposing of an animal whose behaviour directly threatens the life or health of a security guard or other person.

The author shares the opinion that a security guard should have the legal capacity to use weapons in the situations described above.

In the research process, it was also found that it would be desirable to endow the security guards with the same rights they possess in the protected area if they

4 Use of firearms - this is to be understood as a shot at a person using penetration munitions (Grounds: Ustawa z dnia 24 maja 2013 r. o środkach przymusu bezpośredniego i broni palnej - Dz. U. z 2013 r., poz. 628, art. 4. pkt. 7). 
intervene in the immediate vicinity of the facility. It is difficult to separate and treat this area differently, since the situation is dynamic and directly influences its safety. In the author's opinion, the line of the fence should not imply impunity for the perpetrator and the powerlessness of the person protecting the property.

He also believes that it would be legitimate to introduce a legal possibility for a security guard to use a weapon and direct coercion measures (cf. Piwowarski and Pajorski op.cit, p. 50), even outside the protected facility, in the event of a need to fend off an unlawful attempt on life and health. At present, if he uses such means to save the life of an attacked person, he can do so only on the basis of the necessary defence law (Ustawa z dnia 6 czerwca 1997 r. - Kodeks karny, DzU z 1997 r., nr 88, poz. 553, art. $25 \mathbb{\$} 1$ ). This raises some limitations, and the point is that a security guard should not hesitate to come to the person in need.

All proposed changes to the right to use direct coercive measures and the use of firearms by the security guard should, in the view of the author, be taken into account by changing the regulations that govern these issues in two legal acts: the Direct Coverage and Firearms Act (Dz.U. z 2013 r. poz. 628.) and the Personal and Property Protection Act (Dz.U.1997 nr 114 poz.740).

Based on the findings of the study, the author implies that a qualified security guard performing the security tasks, but also when taking the intervention outside the protected facility, could benefit from the legal protection provided for the public officer. This would strengthen the position of security guards against the attackers, who would have a higher qualifying criminal liability for causing harm to the health (or the attack on such a security guard or even insult). The author proposes that the relevant regulation should be included in the Penal Code.

The author notes that a security guard currently has limited capacity to fulfill his right to authorise legal personality. Although he or she can authorise a person in a public place, there is no legal obligation on the part of the person being authorised to present the requested document confirming his or her identity. In the present legal situation, such a refusal is not an offence consisting of not demonstrating a document and, therefore, is not liable under Article 61 pairs. 2 of the Code of Misdemeanors (Ustawa z dnia 20 maja 1971 r. - Kodeks wykroczeń, DzU z 1971 r., nr 12, poz. 114). This liability, in the form of a fine, applies only to persons who have refused to show the document to a representative of a state authority or 
an institution empowered by law to authorise legal personality. Hence, according to the author, it is necessary to introduce a sanctioning regulation in the Code of Misdemeanors, so that failure to present an identity document to a security guard would also be punishable.

Studies have also shown that some companies do not organise training or do it relatively rarely due to the fact that they are not mandatory. Each training means additional costs to the company due to the need to pay employees standard hourly rates for attendance. In addition, you have to pay the shooting range, cover the cost of ammunition and the salaries of instructors and lecturers. In the face of financial difficulties that are particularly affecting the security industry, more and more companies are not choosing to incur extra financial expenses associated with the professional development of their employees. This results in security guards on the labour market who have completed their training in preparation for the profession of a qualified security officer. The obligation of training to improve knowledge and practical skills should be introduced in the Law on the protection of persons and property, and detailed notations should be made on the programme, in a special regulation of the Minister of Internal Affairs.

In the opinion of the author, proper preparation for the profession of security guard is also not favoured by the notation of the amended Law on protection of persons and property (Ustawa z dnia 22 sierpnia 1997 r. o ochronie osób i mienia, DzU z 1997 r., nr 114, poz.740), which have been in force since 1 January 2014. At that time, the first and the second degree licenses had been terminated, and obtaining them was preceded by the necessity for a positive examination result in front of the state commission, appointed by the appropriate local commander of the Voivodeship Police. Verification of the knowledge and skills gained during the preparatory course was made in a test that presented either theoretical or practical features of a candidate. Hence, the view of the author as a result of the concern for the level of training of the security staff, is that the cited law should be changed so that the mandatory state examination for applicants for entry into the list of qualified security personnel is restored into the regulation.

The same act implies that a qualified security guard requires no more than secondary education. Based on the research, the author concluded that this is a requirement that is too minimal since the standards currently being met by security personnel are significantly higher. Contemporary tasks performed by 
a security guard require a good knowledge of legal issues, knowledge of appropriate procedures and their practical application in a crisis situation. Accordingly, the author proposes to implement a requirement for an employee to have at least a college education that would guarantee a perception of the issues mentioned above.

Research has shown that in ensuring security, it is very important to be able to communicate quickly and efficiently between the different entities involved in the process. Research has determined that in most cases, formations such as the Police, Municipal Guard (cf. Fijałkowski 2011) and Fire Brigade do not have a dedicated radio channel where correspondence with the security companies could be hosted. In a crisis situation, such as cataclysm, catastrophe or natural disaster, the simultaneous transmission of current information becomes a key element in the effectiveness of the activities that are being carried out. According to the author, availability of such a radio channel or direct telephone communication is fully justified.

The research shows that there are opportunities for effective cooperation between property and personal security companies and the Police. An analysis of legal acts have revealed that there are no laws that would exclude it, although as already indicated earlier, the majority of Police Commanders consider that since a given area has not been specifically regulated, it does not have the capacity to fulfill it with specific actions. There is also, as was researched in the course of a study, a great deal of distrust in relation to security companies, the fear of transferring information to their employees or their involvement in activities outside the protected area. The author believes that this is unfortunately a loss for a better security system.

The author suggests the following solution: to conclude agreements between county / city commanders of the Police, and property and personal security companies ${ }^{5}$ or with the organisations that are associated with those companies.

5 Administrative Arrangement - a non-administrative form of administrative action bilaterally or a multilateral legal action in the field of administrative law made by entities executing public administration, and coming into effect on the basis of consistent declarations of will of those entities. The subject matter of the agreement is commitment (but not in the civil law) regarding the implementation of tasks in the area of public administration. The agreement provided for either the joint execution of the tasks imposed on the parties being participants of the agreement or the transfer of certain tasks from one entity to another. The administrative agreement on civil law transactions distinguishes primarily the subject of that lies in the area of administrative law and not civil law. Parties to the administrative 
Of course, the very same agreement does not mean that cooperation will be conducted and will bring the expected results. According to the author, it is worth to monitor monitoring such cooperation and designate designating a regular contacts persons responsible for the implementation of such a project. It should also be subject to periodic evaluation, with the possibility of making changes that allow for its current updating. Such an agreement should also specify:

1) exchange of information regarding threats occurring in a given area;

2) organising the communication system for the Police, Municipal guard and security companies;

3) distribution of intervention groups, taking into consideration possible hazards occurring in the area;

4) cooperatation in ensuring peace and order in places of gatherings, artistic, entertainment and sports events, as well as in other public places;

5) assistance in the organisation and conduct of training for security personnel;

6) providing information regarding the observation and recording of incidental technical means in the areas supervised by the security company.

Research has also shown the need to motivate security workers for whom the question of social recognition or prestige is very important. According to the author, the possibility of the local authorities granting awards by the local authorities, with the participation of the local Police, is desirable. An appropriate media coverage would also be important here, this would provide promotion for companies involved in pro-social activities. According to the author, rewards, medals, statuettes and diplomas do not generate high costs, but they give a lot of satisfaction to those who receive them.

On the other hand, the security companies doing charity work for local projects could receive certificates confirming that they are reliable, trustworthy and have a high level of professionalism.

Local self-governments (cf. Art. 7 Ustawy z dnia 8 marca 1990 r. o samorządzie terytorialnym, Dz. U. $1990 \mathrm{nr} 16$ poz. 95), for which such non-compulsory

agreement may be any entities of administrative law, that is also including, entities without legal personality. The terms of reference of the obligations under the agreement must lie with the parties themselves. This means that agreements can be concluded only in the sphere of action of the authorities of the state in which they are independent. (Ochendowski 2002; Wierzbowski 2002). 
activities would be provided by security firms, could relief reduce some of the charges they apply for use of municipal facilities, or apply lower tax rates to those companies. Such solutions could, according to the author, create a real sense of security in the municipality. This is particularly important in a small towns where there is no Municipal Police (Czop 2012, p. 81) or there is no police station.

The research shows that it is possible to intensify the participation of property and persona; security companies in providing public safety in Poland, which was the main research problem. There are also specific directions for change, both in security management and in legislation, which may contribute to a greater use of the large potential of security companies that are not currently satisfactorily integrated into the public security system. This, in turn, can make the system more efficient, which in consequence will raise the level and sense of security that is a fundamental need and a social value.

\section{References}

Ackoff, R. L., 1969. Decyzje optymalne w badaniach stosowanych. PWN, Warsaw.

Bejgier, W. and Stanejko, B., 2010. Ochrona osób i mienia. Wydawnictwa Akademickie i Profesjonalne, Warsaw.

Boon, K., 1999. La function d'enquetedans le secteurprive. In H. S. Becker (ed.), Deviance et societe, Berkeley.

Czop, A., 2012. System bezpieczeństwa publicznego w Polsce. In W. Hrynicki, J. Piwowarski (eds.), Kultura Bezpieczeństwa. Nauka - Praktyka - Refleksje, 12, Kraków.

Czop, A., 2014. Udziat firm ochrony osób i mienia w zapewnianiu bezpieczeństwa publicznego w Polsce, Wydawnictwo Apeiron, Katowice.

Fijałkowski, T., 2011. Straż Gminna, miejska podstawy prawne dziatania, prawa, obowiazki. Wydawnictwo WBG Bogusław Gierakowski, Warsaw.

George, A.L. and Bennett, A., 2005. Case Studies and Theory Development in the Social Sciences. MIT Press, Cambridge.

Gierszewski, J., 2009. Firmy ochrony jako komercyjne organizacje odpowiedzialne za bezpieczeństwo innych podmiotów. In M. Grzybowski (ed.), Logistyka - Komunikacja - Bezpieczeństwo. Wybrane problemy. Gdynia.

Kitler, W., 2004. Obrona cywilna. Wydawnictwo AON, Warsaw.

Kitler, W. and Skrabacz, A., 2003. Wojskowe wsparcie władz cywilnych $i$ spoteczeństwa, Wydawnictwo AON, Warsaw. 
Kolman, R., 2004. Zdobywanie wiedzy. Poradnik podnoszenia kwalifikacji (magisteria, doktoraty, habilitacje). Wyd. „Branta”, Gdańsk.

Korzeniowski, L., 2012. Podstawy nauk o bezpieczeństwie. Difin, Warsaw.

Nowicki, Z. T., 1995. Ochrona osób i mienia. Dom Organizatora, Toruń.

Ochendowski, E., 2002. Prawo Administracyjne. Dom Organizatora, Toruń.

Pajorski, P., 2008. Qui prodest?, BSI Ochrona i Detektywistyka, 7-8.

Palczewski, A. and Stach, W., 1999. Ochrona osób i mienia. Warsaw.

Piwowarski, J. and Pajorski, P., 2015. Ochrona obiektów. Zarys wybranych zagadnień.

Wyższa Szk. Bezpieczeństwa Publicznego i Indywidualnego „Apeiron”, Kraków.

Podgórski, R. A., 2007. Metodologia badań socjologicznych. Kompendium wiedzy metodologicznej dla studentów. Fraszka Edukacyjna, Bydgoszcz.

Rozporządzenie Ministra Spraw Wewnętrznych i Administracji z dnia 18 grudnia 1998 r. w sprawie określenia szczegółowych zasad współpracy specjalistycznych uzbrojonych formacji ochronnych z Policją, jednostkami ochrony przeciwpożarowej, obrony cywilnej i strażami gminnymi (miejskimi), DzU z 1998 r., nr 161 poz. 1108.

Rozwadowski, M., 2014. Doskonalenie systemów zarzadzania bezpieczeństwem ruchu drogowego. Wyższa Szk. Bezpieczeństwa Publicznego i Indywidualnego „Apeiron”, Kraków.

Sawaściuk, E., 2003. Niebieska linia, nr 2., Warsaw.

Sułek, M., 2009. Bezpieczeństwo narodowe jako kategoria, relacyjno-koncepcyjne metody badań. In P. Sienkiewicz, M. Marszałek, H. Świeboda (eds.), Metodologia badań bezpieczeństwa narodowego. Bezpieczeństwo 2010. vol. 1, Wydawnictwo AON, Warsaw.

Szopa T. (ed.), 2009. Niezawodność i bezpieczeństwo. Oficyna Wydawnicza Politechniki Warszawskiej, Warsaw.

Tomczyk, Z., 1999. Firmy ochrony osób i mienia, a bezpieczeństwo społeczności lokalnych. In J. Czapska, W. Krupiarz (eds.), Zapobieganie przestępczości w społecznościach lokalnych. Instytut Spraw Publicznych, Warsaw.

Ustawa z dnia 6 czerwca 1997 r. - Kodeks karny, DzU z 1997 r., nr 88, poz. 553.

Ustawa z dnia 20 maja 1971 r. - Kodeks wykroczeń, DzU z 1971 r., nr 12, poz. 114.

Ustawa z dnia 28 września 1991 o lasach, DzU z 2011 r., nr 12, poz. 59 (tekst ujednolicony)

Ustawa z dnia 5 sierpnia 2010 r. o ochronie informacji niejawnych, DzU z 2010 r., nr 182, poz. 1228.

Ustawa z dnia 22 sierpnia 1997 r. o ochronie osób i mienia, DzU z 1997 r., nr 114, poz.740.

Ustawa z dnia 6 kwietnia 1990 r. o Policji, DzU z 2011 r., nr 287, poz. 1687, z późn. zm.

Ustawa z dnia 9 kwietnia 2010 r. o Służbie Więziennej, DzU z 2010 r., nr 79, poz. 523 z późn. zm. 
Ustawa z dnia 12 października 1990 r. o Straży Granicznej, DzU z 2011 r., nr 116, poz. 6751.

Ustawa o środkach przymusu bezpośredniego i broni palnej, DzU z 2013 r., poz. 628.

Ustawa z dnia 6 września 2001 r. o transporcie drogowym, DzU z 2012 r., poz. 1265 oraz z 2013 r., poz. 21 i 567.

Ustawa z dnia 28 marca 2003 r. o transporcie kolejowym, DzU z 2007 r., nr 16, poz. 94, z późn. zm.

Ustawa z dnia 24 sierpnia 2001 r. o Żandarmerii Wojskowej i wojskowych organach porządkowych, DzU z 2013 r., poz. 568.

Wierzbowski, M., 2002. Prawo Administracyjne. Wydawnictwo Prawnicze LexisNexis, Warsaw.

Wiśniewski, B. (ed.), 2011. Bezpieczeństwo w teorii i badaniach naukowych. Wyd. WSPol, Szczytno.

Wojnarowski, J. and Babula, J., 2004. Bezpieczeństwo militarne Rzeczpospolitej Polskiej. Wydawnictwo AON, Warsaw. 